\title{
Menyoal Pengaturan Anti Eco-Slapp Dalam Undang-Undang Nomor 32 TAHUn $2009^{1}$
}

\author{
Raynaldo Sembiring
}

\begin{abstract}
Abstrak
Anti Eco-SLAPP telah diadopsi dan dirumuskan dalam Pasal 66 UndangUndang Nomor 32 Tahun 2009 tentang Perlindungan dan Pengelolaan Lingkungan Hidup (UU 32/2009). Ketentuan Anti Eco-SLAPP merupakan bentuk perlindungan bagi masyarakat untuk berperan serta dalam memperjuangkan hak atas lingkungan hidup yang baik dan sehat. Hanya saja penjelasan Pasal 66 UU 32/2009 memiliki perbedaan dengan konsep dasar Anti Eco-SLAPP. Selain itu, ketiadaan interpretasi secara resmi terhadap penjelasan Pasal 66 UU 32/2009 berpotensi memberikan menghambat implementasi Anti Eco-SLAPP di Indonesia.

Kata kunci: Anti-SLAPP, Peran Serta Masyarakat, Pasal 66, Hak Atas Lingkungan Hidup Yang Baik dan Sehat

\section{Abstract}

Anti Eco-SLAPP has been adopted and formulated on Article 66's Law No. 32 Year 2009 concerning Environmental Protection and Management. Anti Eco-SLAPP is a form to protection public to participate in implemented rights to environment. However the explanation of Article 66 has diference with the theory of Anti Eco-SLAPP. In addition, the absence of interpretation about explanation of Article 66 give the negative impact the implementation of Anti Eco-SLAPP in Indonesia

Keywords: Anti Eco-SLAPP, Public Participation, Article 66, Rights to Good and Health Environment.

1 Tulisan ini dikembangkan dari makalah “Anti SLAPP Dalam Penegakan Hukum Lingkungan di Indonesia" yang dipresentasikan oleh Penulis pada Konferensi Hukum Lingkungan di Fakultas Hukum Universitas Indonesia, Kamis, 4 Desember 2014. Penulis berterima kasih kepada Fakultas Hukum Universitas Indonesia atas kesempatan mempresentasikan makalah ini.
\end{abstract}




\section{Pendahuluan}

Peran serta masyarakat merupakan bagian penting dalam pengelolaan lingkungan hidup, terutama dalam mencapai pemenuhan haknya atas lingkungan hidup yang baik dan sehat. ${ }^{2}$ Dalam pengelolaan lingkungan hidup, peran serta masyarakat sangat dibutuhkan karena pengelola lingkungan (pengambil kebijakan) biasanya dapat merumuskan persoalan biologis dan teknis secara efektif, namun tidak berhasil dalam menghadapi aspek-aspek sosial dan politik dalam pengelolaan lingkungan ${ }^{3}$. Hal ini yang membuat peran serta masyarakat menjadi faktor penting untuk memperkuat perspektif sosial maupun politik dalam pengambilan kebijakan.

Sherry R. Arnstein menyebutkan bahwa tingkat tertinggi dalam peran serta adalah kontrol oleh masyarakat (citizen control). ${ }^{4}$ Pentingnya kontrol oleh masyarakat dilandasi banyaknya kasus lingkungan hidup yang tidak diimbangi dengan kapasitas pengelola lingkungan hidup yang baik ${ }^{5}$, sehingga membuat upaya pelestarian dan pemulihan lingkungan hidup menjadi tidak optimal.

Kontrol oleh masyarakat juga menjadi faktor penting dalam pengambilan keputusan/kebijakan. Salah satu bentuk pengakuan terhadap kontrol oleh masyarakat dalam pengambilan keputusan/kebijakan adalah Convention on Access to Information, Public Participation in Decision-making and Access to Justice in Environmental Matters ${ }^{6}$ atau yang dikenal dengan Konvensi Aarhus. Konvensi ini memberikan hak bagi masyarakat untuk berperan serta dalam pengambilan keputusan melalui penyampaian pendapat terhadap suatu rencana atau program dengan memberikan ruang untuk menyampaikan pandangannya dengan jangka

2 Hak untuk berperan serta didasarkan dari Pasal $28 \mathrm{H}$ ayat (1) UUD 1945 yang diatur lebih lengkap pada Pasal 65 ayat (1), (3) dan (4) Undang-Undang Nomor 32 Tahun 2009 tentang Perlindungan dan Pengelolaan Lingkungan Hidup.

3 Bruce Mitchell, dkk, Pengelolaan Sumber Daya Lingkungan (Yogyakarta: Gadjah Mada University Press, 2010), hlm. 254.

4 Sherry Arnstein, "Ladder of Citizen Participation", Journal of the American Institute of Planners, (November 2007), hlm. 217.

5 Ahmad Fauzi, dkk, Status Lingkungan Hidup Indonesia, (Jakarta: Kementerian Lingkungan Hidup Republik Indonesia, 2010), hlm. 180-183.

6 The United Nations Economic Commission for Europe (UNECE), Convention on Access to Information, Public Participation in Decision-making and Access to Justice in Environmental Matters, disahkan pada 25 Juni 1998 di Aarhus, Denmark. 
waktu yang efektif dan memadai. ${ }^{7}$ Lebih lanjut, konvensi ini mengakui dan mengatur bahwa peran serta masyarakat dalam pengambilan keputusan akan memperkuat kualitas keputusan dan implementasi dari keputusan tersebut.

Hak masyarakat untuk berperan serta telah diatur sejak Undang-Undang Nomor 4 Tahun 1982 tentang Ketentuan-Ketentuan Pokok Pengelolaan Lingkungan Hidup (UU No. 4/1982) sampai dengan Undang-Undang Nomor 32 Tahun 2009 tentang Perlindungan dan Pengelolaan Lingkungan Hidup (UU 32/2009), sebagaimana terlihat pada tabel di bawah:

Tabel

Perkembangan Pengaturan Hak Untuk Berperan Serta ${ }^{8}$

\begin{tabular}{|l|l|l|}
\hline \multicolumn{1}{|c|}{ UU No. 4/1982 } & \multicolumn{1}{|c|}{ UU No. 23/1997 } & \multicolumn{1}{c|}{ UU No. 32/2009 } \\
\hline $\begin{array}{l}\text { Hak berperan serta } \\
\text { dalam pengelolaan } \\
\text { lingkungan hidup telah } \\
\text { diakui. }\end{array}$ & $\begin{array}{l}\text { Tidak ada perubahan } \\
\text { substansial, hak } \\
\text { berperan serta } \\
\text { pengelolaan } \\
\text { lingkungan hidup } \\
\text { kembali diakui. }\end{array}$ & $\begin{array}{l}\text { Hak berperan serta } \\
\text { diakui sebagai cara } \\
\text { untuk mendapatkan hak } \\
\text { atas lingkungan hidup. } \\
\text { Masyarakat diberikan } \\
\text { akses untuk berperan } \\
\text { serta dalam kegiatan } \\
\text { yang dapat atau telah } \\
\text { menimbulkan dampak } \\
\text { terhadap lingkungan } \\
\text { hidup dan dalam } \\
\text { penegakan hukum. }\end{array}$ \\
& & \multicolumn{2}{l}{} \\
& &
\end{tabular}

Dalam UU 32/2009, pengaturan mengenai peran serta masyarakat mendapat perlindungan hukum sebagaimana diatur pada Pasal 66. Perlindungan hukum ini meliputi perlindungan untuk tidak dapat dituntut pidana maupun digugat perdata, ketika masyarakat berperan serta dalam memperjuangkan hak atas lingkungan hidup yang baik dan sehat.

7 Febby Ivalerina, Demokrasi dan Lingkungan, Jurnal Hukum Lingkungan Indonesia, (Jakarta: ICEL, 2013) hlm. 66. Sebagamana dikutip dari Malgosia Fitzmaurice,Note On The Participation Of Civil Society In Environmental Matters. Case Study: The 1998 Aarhus Convention On Access To Information, Public Participation In Decision-Making And Access To Justice In Environmental Matters, Hum. Rts. \& Int'1 Legal Discourse 47, 2010

8 Disarikan dari Undang-Undang Nomor 4 Tahun 1982, Undang-Undang Nomor 23 Tahun 1997, Undang-Undang Nomor 32 Tahun 2009, dan Undang-Undang Dasar Tahun 1945. 
Konsep Pasal 66 ini dikenal dengan Anti Strategic Lawsuit Against Public Participation (Anti SLAPP). Ketika konsep SLAPP pertama kali dipublikasikan, George W. Pring dan Penelope Canan sebagai penemu konsep ini membagi SLAPP ke dalam beberapa bidang antara lain: pembangunan real estate, perpajakan, lingkungan hidup, dll. Khusus untuk SLAPP yang terjadi di bidang lingkungan hidup, Pring dan Canan mempopulerkan istilah "Eco-SLAPP". ${ }^{9}$ Merujuk kepada Pring dan Canan, karena tulisan ini secara khusus akan membahas SLAPP yang terjadi di bidang lingkungan hidup, maka istilah yang digunakan adalah EcoSLAPP.

Meskipun ketentuan Pasal 66 secara progresif telah memberikan perlindungan agar peran serta masyarakat tidak dapat dituntut pidana maupun digugat perdata, namun masih terdapat beberapa kelemahan pada bagian penjelasannya. Penjelasan Pasal 66 memiliki perbedaan dengan konsep Anti Eco-SLAPP yang dipopulerkan oleh Pring dan Canan serta yang dikenal di negara lain. Perbedaan ini tentunya dapat menghambat implementasi dari Pasal 66 dan mengakibatkan perlindungan terhadap peran serta masyarakat tetap memiliki ruang untuk terjadinya kriminalisasi. Kelemahan dalam penjelasan Pasal 66 ini yang menjadi pokok permasalahan yang diangkat dalam tulisan ini.

Untuk menjawab permasalahan di atas, maka tulisan ini akan dibagi menjadi beberapa bagian. Setelah bagian pendahuluan, bagian kedua akan membahas mengenai konsep dasar Anti Eco-SLAPP. Bagian ketiga akan menjelaskan beberapa contoh kasus Eco-SLAPP di Indonesia, kelemahan pengaturan Anti Eco-SLAPP dalam UU 32/2009 dan usulan perbaikan. Sedangkan bagian terakhir merupakan bagian penutup yang berisi kesimpulan.

Tulisan ini merupakan penelitian hukum dengan menggunakan metode penelitian literatur/penelitian pustaka. Penelitian ini merupakan penelitian deskriptif yang mencoba memaparkan konsep Anti Eco-SLAPP danjuga merupakan penelitian analitis karena menganalisis penerapan Anti Eco-SLAPP dalam praktek.

9 "Eco"-SLAPP dalam hal ini adalah Ecological-SLAPP, yang berarti SLAPP yang terjadi pada kasus-kasus terkait perlindungan ekosistem. Penggunaan istilah ini dapat dilihat pada SLAPPs; Getting Sued for Speaking Out (Philadelpia: Temple University Press, 1996), hlm. 83. 


\section{Anti Eco-SLAPP Sebagai Bentuk Perlindungan Peran Serta Masyarakat}

Pertanyaan paling mendasar mengenai konsep Anti Eco-SLAPP adalah pengertian mengenai SLAPP. Secara sederhana, SLAPP dapat diartikan sebagai tindakan strategis melalui pengadilan untuk menghilangkan partisipasi publik. ${ }^{10}$ Sesuai dengan pengertiannya, tujuan dari SLAPP pada dasarnya untuk membungkam/menghilangkan partisipasi masyarakat. ${ }^{11}$ Sayangnya hingga saat ini, belum ada pengertian yang baku mengenai SLAPP di Indonesia. Namun kita dapat merujuk pengertian di negara lain, seperti di Filipina melalui Rules of Procedures for Environmental Cases, yang memberikan pengertian SLAPP sebagai: ${ }^{12}$

"A legal action filed to harass, vex, exert undue pressure or stifle any legal recourse that any person, institution or the government has taken or may take in the enforcement of environmental laws, protection of the environment or assertion of environmental rights shall be treated as a SLAPP and shall be governed by these Rules."

Terjemahan bebas:

"Sebuah tindakan hukum yang diajukan untuk melecehkan, mengganggu, memberikan tekanan yang tidak semestinya atau menghambat penegakan hukum yang telah dilakukan atau mungkin dilakukan oleh setiap orang, lembaga atau pemerintah dalam penegakan hukum lingkungan, perlindungan terhadap lingkungan hidup atau tuntutan terhadap hak atas lingkungan haruslah diperlakukan sebagai SLAPP dan diatur oleh peraturan ini"

Pengertian yang lebih detail mengenai SLAPP juga dapat dilihat dari AntiSlapp Advisory Panel Report To The Attorney General di Ontario (Kanada), yang kemudian diadopsi dalam Protection of Public Participation Act $2013^{13}$, sebagaimana

10 Istilah ini diciptakan oleh Profesor George W.Pring dan Dr. Penelope Canan, sebagaimana dikutip oleh Dwight H.Merriam dan Jeffrey A.Benson dalam tulisan "Identifying and Beating a Strategic Lawsuit Against Public Participation", http:// scholarship.law.duke.edu/ cgi/viewcontent.cgi?article=1214\&context=delpf, hlm. 17, diunduh pada April 2014.

11 Fiona Dobson, “Legal Intimidation" (New York, 2000), sebagaimana dikutip oleh Josi Khatarina dalam "SLAPP In Indonesia: How It Takes Its Forms And How To Beat It", hlm. 2.

12 Republic of The Philippines Supreme Court, Rules of Procedures for Environmental Cases, Section 1 Rule 6.

13 http://www.fasken.com/anti-slapp-legislation-ontario-protection-of-public-participationact/,diakses pada 29 Maret 2017. 
disebutkan:

“... a lawsuit initiated against one or more individuals or groups that speak out or take a position on an issue of public interest. SLAPPs use the court system to limit the effectiveness of the opposing party's speech or conduct. SLAPPs can intimidate opponents, deplete their resources, reduce their ability to participate in public affairs, and deter others from participating in discussion on matters of public interest"

Terjemahan bebas:

“...sebuah tindakan/gugatan hukum yang dilakukan terhadap seorang atau beberapa orang atau kelompok yang menyampaikan pendapat atau sikap terhadap sebuah isu yang berkaitan dengan kepentingan publik. SLAPPs menggunakan sistem pengadilan untuk membatasi efektivitas pendapat atau tindakan pihak lawan. SLAPPs dapat mengintimidasi lawan, menguras sumber dayanya, mengurangi kesempatan untuk berpartisipasi dalam urusan publik dan mencegah untuk berpartisipasi dalam masalahmasalah yang menyangkut kepentingan publik."

Pengertian di atas menunjukan bahwa SLAPP dapat terjadi tidak hanya pada kasus lingkungan hidup saja, melainkan juga pada kasus lain yang menyangkut kepentingan publik. Awal munculnya konsep SLAPP adalah ketika Pring dan Canan terinspirasi dari kasus yang dihadapi oleh seorang environmental lawyer di Denver (USA), dimana kliennya yang sedang memperjuangkan haknya atas lingkungan hidup yang sehat digugat oleh pemerintah dan pencemar. ${ }^{14}$ Setelah itu, Pring dan Canan juga menemukan banyak kasus lain yang menyangkut kepentingan publik yang mendapat perlawanan balik dari pemerintah maupun pihak lain yang mendapatkan keuntungan dari kebijakan pemerintah. Padahal hampir dari seluruh kasus tersebut terjadi ketika masyarakat menggunakan haknya untuk berpartisipasi, menuliskan keberatan atas sebuah rencana atau program melalui surat kabar, menyampaikan keberatan atau mengajukan petisi terhadap sebuah kebijakan. Hak untuk mengajukan petisi sendiri telah dijamin oleh Amandemen Pertama Konstitusi USA. ${ }^{15}$

14 George W. Pring and Penelope Canan, SLAPPs; Getting Sued for Speaking Out, ix.

15 https://www.law.cornell.edu/constitution/first_amendment, diakses pada 29 Maret 2017. 
Pring dan Canan melihat bahwa kasus-kasus tersebut lebih dari sebuah fenomena hukum yang belum terselesaikan, melainkan juga berdampak buruk terhadap aspek sosial dan politik yang tidak hanya dirasakan oleh masyarakat yang mengalami $S L A P P$, atau mereka yang terlibat dalam gerakan untuk berperan serta, melainkan juga terhadap masa depan dari peran serta masyarakat dalam demokrasi di USA. ${ }^{16}$ Kasus-kasus tersebut yang menjadi acuan bagi Pring dan Canan untuk melakukan penelitian yang kemudian melahirkan konsep Anti-SLAPP. Konsep Anti-SLAPP dilahirkan karena keyakinan Pring dan Canan bahwa kebebasan menyampaikan pendapat, berperan serta dalam masalah-masalah yang menyangkut kepentingan publik adalah bagian dari tindakan berdemokrasi yang dilindungi oleh Konstitusi USA. Hal ini tidak jauh berbeda dengan Indonesia, dimana Amandemen Kedua Undang-Undang Dasar 1945 (UUD 1945) telah menjamin hak bagi setiap orang untuk mengeluarkan pendapat. ${ }^{17}$ Lebih khusus lagi Undang-Undang Nomor 39 Tahun 1999 tentang Hak Asasi Manusia (UU HAM) juga menjamin hak setiap orang untuk mengajukan pendapat, permohonan, pengaduan, dan atau usulan kepada pemerintah dalam rangka pelaksanaan pemerintahan yang bersih, efektif, dan efisien. ${ }^{18}$ Hal ini menunjukan bahwa konsep Anti SLAPP dapat diterapkan secara umum dalam perundangan-undangan di Indonesia.

Jika merujuk kepada Anti-Slapp Advisory Panel Report To The Attorney General, terlihat bahwa SLAPP umumnya terjadi pada masalah-masalah yang menyangkut kepentingan publik. Masalah-masalah ini tentunya dapat terjadi pada semua bidang, yang tidak terbatas pada masalah pengelolaan lingkungan hidup saja. Adapun konsep Anti Eco-SLAPP tidaklah berbeda dengan konsep Anti-SLAPP pada umumnya, melainkan hanya kekhususan terhadap SLAPP yang terjadi di bidang lingkungan hidup.

Hanya saja tidak sedikit kasus Anti-Eco SLAPP memiliki relasi dengan berbagai bidang lainnya seperti yang terjadi pada kasus "Gunss 20" di Australia. Kasus ini bermula ketika Gunss yang merupakan perusahaan besar yang memiliki bidang usaha kayu menggugat 20 aktivis lingkungan (3 organisasi lingkungan dan 17 individu $)^{19}$ dikarenakan kampanye mereka untuk melindungi hutan di Tasmania.

16 George W. Pring and Penelope Canan, SLAPPs; Getting Sued for Speaking Out, x.

17 Pasal 28E ayat (3) Undang-Undang Dasar 1945.

18 Pasal 44 Undang-Undang Nomor 39 Tahun 1999 tentang Hak Asasi Manusia.

19 http://www.activistrights.org.au/handbook/ch04s01.php, diakses pada 11 April 2017. 
Gunss mengklaim mengalami kerugian lebih dari AUD\$ 6 juta dengan tuduhan bahwa para aktivis telah bersekongkol satu sama lain untuk mengganggu bisnis dan hubungan kontraktual Gunss yang dilakukan secara melawan hukum, dengan melakukan lobi ke Bank dan konsumen Jepang serta menyampaikan laporan ke media. Lebih jauh, Gunss menuduh bahwa para aktivis bersekongkol dalam kampanye melawan Gunss sebagai perusahaan. ${ }^{20}$ Kasus “Gunss 20" menjadi cikal bakal trend baru SLAPP di Australia. Melalui kasus ini, gugatan ganti kerugian atas gangguan perdagangan atau gangguan terhadap hubungan kontrak, dan tindakan lainnya di bawah undang-undang praktek perdagangan menjadi trend baru SLAPP. Kasus ini juga memperlihatkan relasi Eco-SLAPP dengan bidang lainnya yaitu perdagangan.

Tindakan SLAPP tidak dapat diidentifikasi dengan mudah. Hal ini karena prosedur hukum yang digunakan adalah sah. Untuk mengidentifikasi apakah sebuah tindakan dapat dikategorikan sebagai SLAPP, Pring dan Canan menyebutkan empat kriteria sebuah tuntutan/gugatan merupakan SLAPP, yaitu: ${ }^{21}$

(1) Adanya keluhan, pengaduan dan tuntutan dari masyarakat;

(2) Adanya komunikasi yang dilakukan oleh masyarakat kepada pemerintah atau pejabat yang berwenang atas keluhan, pengaduan dan tuntutan tersebut;

(3) Keluhan, pengaduan dan tuntuan tersebut dilakukan berdasarkan isu yang menyangkut kepentingan umum atau perhatian publik; dan

(4) (SLAPP) diajukan terhadap individu non-pemerintah atau kelompok.

Dalam kasus “Gunss 20" kriteria (1) dan (2) terlihat ketika 20 aktivis mengkampanyekan perlindungan hutan Tasmania baik melalui media maupun langsung kepada pejabat yang berwenang. Kriteria (3) terlihat ketika isu yang dikampanyekan merupakan isu perlindungan lingkungan hidup yang tentunya berkaitan dengan kepentingan umum atau perhatian publik. Sebagai catatan, isu mengenai perlindungan hutan Tasmania merupakan isu yang sangat sensitif selama 20 tahun terakhir. Sedangkan kriteria (4) terlihat ketika Gunss menggugat 20 aktivis yang terdiri dari 3 organisasi dan 17 individu.

20 Greg Ogle, “Anti-SLAPP Law Reform in Australia”, (Blackwell Publishing, 2010), hlm. 39.

21 George W Pring and Penelope Canan, SLAPPS; Getting Sued for Speaking Out (1 $1^{\text {st }}$ edition, 1996), 8. Sebagaimana dikutip oleh Dwight H.Merriam and Jeffrey A.Benson, Identifying and Beating a Strategic Lawsuit Againts Public Participation, hlm. 18. 
Dalam perkembangannya, Dwight H. Merriam and Jeffrey A. Benson menambahkan kriteria kelima, yaitu SLAPP dilakukan tanpa dasar yang kuat dan mengandung motif politik atau motif ekonomi tersembunyi. ${ }^{22}$ Kelima kriteria tersebut tentunya dapat terus berkembang mengikuti kondisi yang terjadi. Dari kriteria yang disampaikan oleh Pring dan Canan dapat dilihat bahwa pada umumnya yang menjadi "target dan korban" dari tindakan SLAPP adalah masyarakat, organisasi non pemerintah, jurnalis, dan media. ${ }^{23}$

SLAPP dapat terjadi dengan berbagai cara, antara lain: fitnah, gangguan yang mempengaruhi aktivitas sehari-hari, gangguan yang dilakukan terhadap pribadi (privat), konspirasi, tindakan yang berbahaya, tindakan yang menimbulkan kerugian, dan seterusnya. ${ }^{24}$ Fitnah merupakan tipe yang paling umum terjadi pada kasus SLAPP. ${ }^{25}$ Namun, tipe lainnya terus berkembang seiring dengan semakin banyaknya peran serta masyarakat untuk mengkritisi bahkan menolak beberapa kebijakan yang menyangkut kepentingan publik, khususnya di bidang lingkungan hidup dan sumber daya alam.

\section{Praktik Eco-SLAPP dan Ketentuan Anti Eco-SLAPP di Indonesia}

Usulan pengaturan mengenai Anti Eco-SLAPP disuarakan pertama kali dalam Rapat Dengar Pendapat Umum (RDPU) dengan beberapa organisasi lingkungan hidup pada pembahasan Rancangan Undang-Undang tentang Pengelolaan Lingkungan Hidup. ${ }^{26}$ Beberapa alasan yang melatarbelakangi perlunya pengaturan ini antara lain: ${ }^{27}$

22 Dwight H.Merriam and Jeffrey A.Benson, "Identifying and Beating a Strategic Lawsuit Against Public Participation 18.

23 Josi Khatarina, “SLAPP In Indonesia: How It Takes Its Forms And How To Beat It", Melbourne Law Masters Paper, 25 September 2008, hlm. 6.

24 James A. Wells, "Exporting SLAPPS: International Use of the US SLAPP” To Suppress Dissent and Critical Speech, Temple International Comparative Law Journal, 1998.

25 Josi Khatarina, “SLAPP In Indonesia: How It Takes Its Forms And How To Beat It”, hlm.7.

26 RUU Pengelolaan Lingkungan Hidup merupakan inisiatif dari DPR atas revisi UU No. 23 Tahun 1997 tentang Pengelolaan Lingkungan Hidup, yang kemudian dalam perumusannya judulnya menjadi Undang-Undang tentang Perlindungan dan Pengelolaan Lingkungan Hidup.

27 Dewan Perwakilan Rakyat Republik Indonesia, "Risalah RUU tentang Pengelolaan Lingkungan Hidup", (Jakarta: Dewan Perwakilan Rakyat Republik Indonesia, 2009), hlm. 20. 
(1) Sering terjadinya pembungkaman terhadap masyarakat yang memperjuangkan kepentingan lingkungan oleh pemerintah atau pihak-pihak lain yang berwenang.

(2) Sering terjadinya pelaporan balik dengan dalil pencemaran nama baik kepada masyarakat yang melaporkan kasus lingkungan hidup kepada pihak yang berwajib.

Usulan adanya ketentuan mengenai Anti Eco-SLAPP ini disetujui oleh para perumus UU 32/2009. Para perumus berpendapat bahwa ketentuan ini penting sebagai sarana perlindungan bagi peran serta masyarakat untuk mewujudkan lingkungan hidup yang baik dan sehat. ${ }^{28}$

Praktik Eco-SLAPP dapat dianalogikan seperti fenomena gunung es, dimana kasus yang terungkap ke publik sangat sedikit, dibandingkan dengan jumlah konflik dan perkara-perkara di bidang lingkungan hidup dan sumber daya alam. Di Indonesia, Eco-SLAPP telah terjadi sebelum adanya ketentuan Anti Eco-SLAPP dalam UU 32/2009. Berikut ini akan disampaikan beberapa kasus Eco-SLAPP terhadap peran serta masyarakat baik sebelum dan sesudah UU 32/2009.

1. Dr. Rignolda Djamaluddin vs PT $N M R^{29}$

Dr. Rignolda adalah seorang ahli lingkungan yang berfokus pada konteks dinamika lingkungan pantai yang juga merupakan Direktur Kelola (sebuah lembaga konservasi lingkungan). Dr. Rignolda menyampaikan pendapatnya kepada media sesuai dengan keahlian dan keberpihakannya sebagai aktivis lingkungan terhadap pencemaran yang dilakukan oleh PT.Newmont Minahasa Raya (PT NMR) di Teluk Buyat. Dr. Rignolda menyatakan bahwa telah terjadi pencemaran di Teluk Buyat yang menyebabkan penyakit minamata yang diidap oleh masyarakat sekitar Teluk Buyat. ${ }^{30}$ Pernyataan Dr. Rignolda pada Harian Kompas 20 Juli 2004 dan Sinar Harapan 21 Juli 2004 mengenai operasi

28 Hal ini terlihat dari pendapat beberapa anggota Pansus yang setuju bahwa pentingnya perlindungan bagi masyarakat yang memperjuangkan hak atas lingkungan hidup yang baik dan sehat. Lihat: "Risalah RUU tentang Pengelolaan Lingkungan Hidup", Rapat Panja tanggal 28 Juli 2009, hlm. 33.

29 Putusan Nomor 278/PDT.G/2004/PN Manado

30 Lihat http://www.minesandcommunities.org/article.php?a=1391, diunduh pada 13 Desember 2013. 
penambangan yang dilakukan PT. NMR ${ }^{31}$ akhirnya membuat PT NMR menggugat Dr. Rignolda dengan gugatan pencemaran nama baik.

\section{Negara RI vs. Yani Saragoa}

Yani Saragoa adalah seorang aktivis lingkungan yang memberikan perhatian terhadap kasus pencemaran limbah (tailing) yang diduga dilakukan oleh PT Newmont Nusa Tenggara. Yani Saragoa memberikan pernyataan tentang dugaannya, bahwa penyakit yang diderita oleh mayoritas masyarakat Tonggo Sejorong (Sumbawa) diakibatkan oleh limbah yang dihasilkan oleh PT. Newmont Nusa Tenggara. Pernyataan tersebut dibuatnya dalam bentuk press release kemudian disebarkan ke media dan masyarakat. PT Newmont tidak terima perbuatan Yani Saragoa dan menganggap bahwa tindakan Yani Saragoa adalah pemfitnahan yang telah mencemarkan nama baik PT Newmont Nusa Tenggara. Kemudian PT Newmont Nusa Tenggara melaporkan perbuatan Yani Saragoa dengan dalil pencemaran nama baik. ${ }^{32}$

\section{H. Rudy vs Willy Suhartanto ${ }^{33}$}

H. Rudy merupakan pengurus Forum Masyarakat Peduli Mata Air (FMPA) yang memperjuangkan agar pembangunan The Rayja Batu Resort dihentikan karena dapat memberikan dampak negatif bagi sumber mata air gemulo di Kota Batu. Adapun alsannya karena pembangunan The Rayja Batu Resort hanya berjarak sekitar 150 meter dari sumber mata air yang dapat mengancam kehidupan masyarakat sekitar sebagai penggunanya. Atas tindakan yang dilakukan oleh H. Rudy, Willy Suhartanto sebagai Direktur PT. Panggon Sarkarya Sukses Mandiri yang bertanggungjawab dalam membangun The Rayja Batu Resort menggugat H. Rudy dengan dalil bahwa tindakan H. Rudy yang berperan serta dengan mengirimkan surat pengaduan dan pelaporan kepada instansi pemerintah, anggota DPR, dan institusi pendidikan atas pembangunan The Rayja Batu Resort yang dapat mengancam kerusakan lingkungan hidup dianggap sebagai perbuatan melawan hukum.

31 Lihat groups.yahoo.com/neo/groups/kmnu2000/conversations/topics/15707?var=0, pernyataan yang bersifat "Urgent Action" dari Elsam bernomor : 08/PH/XI/ELSAM/04, solidaritas terhadap Dr.Rignolda Djamaludin (Oda), aktivis, Direktur Kelola, Manado, diunduh pada 5 Januari 2014.

32 Putusan Nomor $1212 \mathrm{~K} / \mathrm{Pid} / 2006$.

33 Putusan Nomor 177/Pdt.G/2013/PN.Mlg 
Ketiga kasus yang diuraikan di atas dapat disebut sebagai Eco-SLAPP, karena peran serta yang dilakukan oleh Dr. Rignolda, Yani Saragoa, dan H. Rudy dalam rangka memperjuangkan lingkungan hidup yang baik dan sehat. Bentuk peran serta yang dilakukan juga dijamin oleh Pasal 28E ayat (3) UUD 1945 dan Pasal 44 UU HAM. Kasus SLAPP yang dialami oleh Dr. Rignolda dan Yani Saragoa, terjadi sebelum tahun 2009, dimana belum ada pengaturan mengenai Anti EcoSLAPP. Sedangkan kasus yang dialami oleh H. Rudy terjadi setelah UU 32/2009 diundangkan.

Putusan majelis hakim terhadap ketiga kasus ini juga berbeda. Dr. Rignolda yang sempat dinyatakan melakukan perbuatan melawan hukum pada Pengadilan Tingkat Pertama dan Pengadilan Tingkat Banding, dibebaskan pada Putusan Kasasi. Sedangkan permohonan kasasi yang diajukan Yani ditolak oleh Mahkamah Agung sehingga harus menjalani kurungan selama 4 (empat) bulan. Nasib lebih baik awalnya dialami oleh $\mathrm{H}$. Rudy ketika Majelis Hakim pada Pengadilan Negeri Malang dan Pengadilan Tinggi Surabaya menyatakan Willy Suhartanto melakukan perbuatan melawan hukum dan memerintahkan pembangunan PT. Rayja Batu Resort dihentikan. Namun dikemudian hari Putusan Kasasi Mahkamah Agung membatalkan putusan Pengadilan Tinggi Surabaya.

Dalam kasus H. Rudy vs Willy Suhartanto, Pasal 66 UU 32/2009 sudah digunakan yang dalam eksepsi kuasa hukum H. Rudy yang menyebutkan Willy Suhartanto telah melakukan SLAPP. Walaupun dalam pertimbangannya majelis hakim Pengadilan Negeri Malang dan Pengadilan Tinggi Surabaya tidak mempertimbangkan Eco-SLAPP yang terjadi. Setelah perkara ini, praktis belum ada lagi perkara mengenai Anti Eco-SLAPP.

Dari ketiga kasus Eco-SLAPP di atas, terlihat bahwa peran serta yang dilakukan sesuai dengan perundang-undangan pun masih memberikan ruang terjadinya kriminalisasi. Pertanyaan yang kemudian muncul adalah apakah ketentuan Anti Eco-SLAPP dalam UU 32/2009 telah cukup jelas bagi perlindungan hak masyarakat untuk berperan serta? Untuk menjawab pertanyaan ini, maka kita perlu melihat ketentuan Pasal 66 dan penjelasannya.

Pasal 66

“Setiap orang yang memperjuangkan hak atas lingkungan hidup yang 
baik dan sehat tidak dapat dituntut secara pidana maupun digugat secara perdata."

Penjelasan

“Ketentuan ini dimaksudkan untuk melindungi korban dan/atau pelapor yang menempuh cara hukum akibat pencemaran dan/atau perusakan lingkungan hidup. Perlindungan ini dimaksudkan untuk mencegah tindakan pembalasan dari terlapor melalui pemidanaan dan/atau gugatan perdata dengan tetap memperhatikan kemandirian peradilan." (cetak tebal dari penulis).

Ketentuan Pasal 66 UU 32/2009 telah memberikan perlindungan hukum bagi peran serta masyarakat. Walaupun tidak ada pengertian mengenai apa yang dimaksud dengan Anti Eco-SLAPP, namun pengaturan ini sudah cukup untuk diterjemahkan lebih detail dalam peraturan pelaksana atau peraturan internal pada masing-masing institusi penegakan hukum.

Masalah sesungguhnya terdapat pada penjelasan Pasal 66 UU 32/2009, yaitu pada penggalan kalimat: (1) “....melindungi korban dan/atau pelapor yang menempuh cara hukum.." dan (2) "....untuk mencegah tindakan pembalasan dari terlapor....". Kedua poin ini dapat menimbulkan penafsiran bahwa perlindungan bagi masyarakat yang berperan serta mewujudkan lingkungan hidup yang baik dan sehat hanya dapat diberikan ketika masyarakat telah menempuh proses persidangan. Artinya penjelasan Pasal 66 kontraproduktif dengan Pasal 66 itu sendiri. Padahal jika melihat tipe SLAPP yang disampaikan oleh James A.Wells ${ }^{34}$, tindakan SLAPP dapat terjadi ketika masyarakat tidak atau belum menempuh proses persidangan.

Konsep Anti Eco-SLAPP yang dikembangkan oleh Pring dan Canan juga tidak membatasi perlindungan hanya ketika target atau korban Eco-SLAPP telah menempuh prosedur hukum. Untuk lebih jelasnya kita dapat melihat bagaimana ketentuan Rules of Procedure for Environmental Cases mengatur perlindungan bagi target atau korban Eco-SLAPP:35

34 James A Wells, "Exporting SLAPPS: International Use of the US SLAPP”

35 Republic of The Philippines Supreme Court, Rules of Procedures for Environmental Cases, Section 2 Rule 6. 
"In a SLAPP filed against a person involved in the enforcement of environmental laws, protection of the environment, or assertion of environmental rights, the defendant may file an answer interposing as a defense that the case is a SLAPP and shall be supported by documents, affidavits, papers and other evidence; and, by way of counterclaim, pray for damages, attorney's fees and costs of suit."

Terjemahan bebas:

“Dalam SLAPP yang diajukan terhadap orang yang terlibat dalam penegakan hukum lingkungan, perlindungan lingkungan, atau pengakuan atas hak-hak lingkungan, terdakwa/tergugat dapat mengajukan jawaban sebagai pembelaan bahwa kasus tersebut adalah SLAPP yang harus didukung oleh dokumen, keterangan tertulis, kertas dan bukti lain; dan, dengan cara balasan, biaya pengacara dan biaya lainnya."

Rules of Procedure for Environmental Cases menunjukan bahwa Anti EcoSLAPP dapat diterapkan pada situasi apa saja, dengan catatan seseorang atau komunitas sedang atau telah melaksanakan haknya untuk berperan serta (baik dalam penegakan hukum maupun dalam merespon sebuah kebijakan) dalam perlindungan dan pengelolaan lingkungan hidup.

Terhadap penjelasan Pasal 66 yang mengaburkan konsep Anti-Eco SLAPP, Mahkamah Agung (MA) melalui keputusan Ketua MA Nomor: 36/KMA/SK/ II/2013 tentang Pemberlakuan Pedoman Penanganan Perkara Lingkungan Hidup (SK KMA 36/2013), telah memberikan penjelasan. Dalam SK KMA 36/2013 disebutkan bahwa:

“Anti SLAPP merupakan perlindungan hukum bagi pejuang lingkungan hidup, gugatan SLAPP dapat berupa gugatan balik (gugatan rekonvensi), gugatan biasa atau berupa pelaporan telah melakukan tindak pidana bagi pejuang lingkungan hidup (misalnya, dianggap telah rnelakukan perbuatan "penghinaan" sebagaimana diatur dalam KUHP)." ${ }^{36}$

Dari penjelasan SK KMA 36/2013 terlihat bahwa MA menafsirkan Eco-SLAPP dapat terjadi kapan saja baik ketika masyarakat tidak atau belum menempuh proses persidangan. Penjelasan ini sama dengan pengaturan dalam Rules of Procedure

36 Ketua MA Nomor: 36/KMA/SK/II/2013 tentang Pemberlakuan Pedoman Penanganan Perkara Lingkungan Hidup, hlm. 20. 
for Environmental Cases. Namun SK KMA 36/2013 tetap memiliki keterbatasan sebagaimana disebutkan bahwa:

“Untuk memutuskan scbagaimana dalam Pasal 66 Undang-Undang Republik Indonesia Nomor 32 Tahun 2009 tentang Perlindungan dan Pengelolaan Lingkungan Hidup bahwa gugatan penggugat dan/atau pelaporan tindak pidana dari pemohon adalah $S L A P P$ yang dapat diajukan baik dalam provisi, eksepsi maupun dalam gugatan rekonvensi (dalam perkara perdata) dan/atau pembelaan (dalam perkara pidana) dan harus diputuskan lebih dahulu dalam putusan sela." ${ }^{37}$ (cetak tebal dari penulis).

Keterbatasan dalam penjelasan ini terlihat pada penanganan perkara EcoSLAPP pada perkara pidana. Jika pada kasus perdata, MA memberikan opsi bagi tergugat untuk mengajukan eksepsi bahwa ia mendapat Eco-SLAPP, namun tidak sama halnya dengan penanganan perkara pidana. Dalam penanganan perkara pidana, tersangka/terdakwa Eco-SLAPP telah melalui serangkaian proses panjang mulai dari penyidikan. Hal ini sangat memungkinkan terjadinya pelanggaran HAM melalui upaya paksa, misalnya melalui penangkapan, penahanan, dan lainnya. Artinya, SK KMA 36/2013 memiliki keterbatasan karena hanya dapat melindungi tersangka/terdakwa Eco-SLAPP setelah perkara tersebut diperiksa di pengadilan. SK KMA 36/2013 tentunya sudah cukup memberikan perlindungan bagi hak masyarakat untuk berperan serta. Tentunya dibutuhkan komitmen serupa dari instansi penegakan hukum lain seperti Kementerian Lingkungan Hidup dan Kehutanan, Kepolisian RI dan Kejaksaan Agung untuk memberikan penafsiran atas penjelasan Pasal 66 dalam rangka implementasi konsep Anti EcoSLAPP khususnya perlindungan terhadap hak masyarakat untuk berperan serta.

\section{Simpulan}

Tulisan ini menunjukan bahwa konsep Anti Eco-SLAPP masih belum dapat diimplementasikan secara optimal di Indonesia. Hal pertama yang perlu dilakukan adalah membuat pengertian resmi mengenai Anti Eco-SLAPP. Pengertian resmi ini menjadi penting sebagai acuan penanganan perkara Anti Eco-SLAPP dalam persidangan perdata maupun pidana. Tentunya KLHK yang paling tepat untuk

37 Ibid. 
membuat pengertian ini. Selain itu, diperlukan juga adanya penafsiran atas penjelasan Pasal 66 oleh KLHK, Kepolisian RI dan Kejaksaan Agung. Penafsiran ini dapat mencontoh penafisiran MA dalam SK KMA 36/2013. 


\section{DAFTAR PUSTAKA}

\section{Buku}

Fauzi, Ahmad, dkk. Status Lingkungan Hidup Indonesia. Jakarta: Kementerian Lingkungan Hidup Republik Indonesia, 2010.

Mitchell, Bruce., dkk. Pengelolaan Sumber Daya Lingkungan. Yogyakarta: Gadjah Mada University Press, 2010.

Pring, George W and Penelope Canan. SLAPPs; Getting Sued for Speaking Out .1 $1^{\text {st }}$ edition, 1996.

Santosa, Mas Achmad. Good Governance dan Hukum Lingkungan. Jakarta: Indonesian Center for Environmental Law, 2001.

Sembiring, Raynaldo, dkk. Anotasi Undang-Undang Nomor 32 Tahun 2009 tentang Perlindungan dan Pengelolaan Lingkungan Hidup. Jakarta: Indonesian Center for Environmental Law, 2014.

\section{Artikel Jurnal}

Ogle, Greg, “Anti-SLAPP Law Reform in Australia”, Blackwell Publishing, 2010.

Sembiring, Raynaldo. "Kriminalisasi atas Partisipasi Masyarakat: Menyisir Kemungkinan terjadinya SLAPP terhadap Aktivis Lingkungan Hidup Sumatera Selatan", Jurnal Hukum Lingkungan Indonesia, vol.1 (Januari, 2014): 207-218.

Sherry Arnstein, "Ladder of Citizen Participation". Journal of the American Institute of Planners, (November 2007): 216-224.

Wells, James A. "Exporting SLAPPS: International Use of the US SLAPP" To Suppress Dissent and Critical Speech, Temple International Comparative Law Journal, 1998.

\section{Makalah}

Khatarina, Josi. "SLAPP In Indonesia: How It Takes Its Forms And How To Beat It", Melbourne, 25 September 2008.

\section{Peraturan Perundang-undangan}

Undang-Undang Dasar Negara Republik Indonesia Tahun 1945.

Undang-Undang Nomor 32 Tahun 2009 tentang Perlindungan dan Pengelolaan Lingkungan Hidup.

Undang-Undang Nomor 39 Tahun 2004 tentang Hak Asasi Manusia

Undang-Undang Nomor 23 Tahun 1997 tentang Pengelolaan Lingkungan Hidup. 
Undang-Undang Nomor 4 Tahun 1982 tentang Ketentuan-Ketentuan Pokok Pengelolaan Lingkungan Hidup.

Republic of The Philippines Supreme Court, Rules of Procedures for Environmental Cases.

\section{Putusan Pengadilan}

Putusan Pengadilan Negeri Malang Nomor 177/Pdt.G/2013/PN.Mlg.

Putusan Mahkamah Agung Nomor 1212 K/Pid/2006.

Putusan Pengadilan Negeri Manado Nomor 278/PDT.G/2004/PN Manado.

\section{Internet}

The United Nations Economic Commission for Europe (UNECE), Convention on Access to Information, Public Participation in Decision-making and Access to Justice in Environmental Matters, http://ec.europa.eu/environment/aarhus/ , diunduh pada 11 April 2017

https:// www.kontras.org/data/Protap $\%$ 20Kapolri $\% 20$ No $\% 201 \% 20$ tahun $\% 20$ 2010.pdf, diunduh pada 27 November 2014.

"Declaration of The United Nations Conference on the Human Environment", http://www.unep.org/Documents.Multilingual/Default.Print.asp?documen tid=97\&articleid=1503, diunduh pada 26 November 2014.

"Rio Declaration on Environment and Development", http://www.unep.org/ Documents.Multilingual/Default.asp?DocumentID=78\&ArticleID=1163 ， diunduh pada 24 September 2014.

"Identifying and Beating a Strategic Lawsuit Against Public Participation", http:// scholarship.law.duke.edu/cgi/viewcontent.cgi?article $=1214 \&$ context $=$ delpf, diunduh pada April 2014.

groups.yahoo.com/neo/groups/kmnu2000/conversations/topics / 15707?var=0 , pernyataan yang bersifat "Urgent Action" dari Elsam bernomor : 08/PH/ XI/ELSAM/04, solidaritas terhadap Dr.Rignolda Djamaludin (Oda), aktivis, Direktur Kelola, Manado, diunduh pada 5 Januari 2014.

http://www.minesandcommunities.org/article.php?a=1391, diunduh pada 13 Desember 2013.

\section{Sumber lain}

Dewan Perwakilan Rakyat Republik Indonesia, "Risalah RUU tentang Pengelolaan Lingkungan Hidup". Jakarta: Dewan Perwakilan Rakyat Republik Indonesia, 2009. 